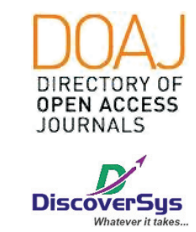

Published by DiscoverSys

\title{
Hubungan lama duduk terhadap nyeri punggung bawah miogenik dan faktor-faktor yang berhubungan pada pengerajin kain tenun di Desa Sidemen, Kecamatan Sidemen, Kabupaten Karangasem tahun 2017
}

\author{
Ida Ayu Dyah Yusa Dhammayanthi, ${ }^{1 *}$ Susy Purnawati, ${ }^{2}$ Made Muliarta ${ }^{2}$
}

\section{ABSTRACT}

Lower back pain (NPB) is a major cause of disability affecting work and general welfare of workers.

Aim: The study aims to determine the long sitting relationship to the lower back pain of miogenik and factors related to the weaving fabric in the village of Sidemen so that the results of the study can be used as a confirmatory study.

Method: This study uses cross-sectional analytic design with the research sample are all respondents with low back pain complaints as appropriate with the inclusion criteria. The sample was chosen by purposive sampling technique with minimum number is 76 samples.

Result: The results of the study showed that the largest number of samples were based on female gender groups $85.5 \%$ (65 people), age $25-50$ years $75.0 \%$ (57 people), tenure $>10$ years $90.8 \%$ (69 people), BMI not at risk ( $\leq 29.9)$ of $63.2 \%$ (48 people), for sporting habits 1 time a week $94.7 \%$ (72 people), based on Pain Disability Index (PDI) disrupted with PDI 0-35 score of 96, 1\% (73 people), based on sitting time $>4$ hours of $81.6 \%$ (62 people), and for lower back pain complaints no NPB of $64.5 \%$ (49 people).

Conclusion: Exact Fisher test results obtained $\mathrm{p} 0.011$ which indicates that $\mathrm{Ho}$ is rejected which means there is a relationship between the sitting time to lower back pain miogenik on artisans of woven fabrics in the village of Sidemen. PR (prevalence ratio) was found to be 5,871 which means woven craftsman who sat $>4$ hours 5,871 times more risky to experience lower back pain than sitting $<4$ hours.

Keywords: Lower Back Pain (NPB), length of seat, woven craftsman.

Cite This Article: Dhammayanthi, I.A.D.Y., Purnawati, S., Muliarta, M. 2020. Hubungan lama duduk terhadap nyeri punggung bawah miogenik dan faktor-faktor yang berhubungan pada pengerajin kain tenun di Desa Sidemen, Kecamatan Sidemen, Kabupaten Karangasem tahun 2017. Intisari Sains Medis 11(2): 878-883. D0I: 10.15562/ism.v11i2.226

\section{ABSTRAK}

Nyeri punggung bawah (NPB) tersebut merupakan penyebab utama kecacatan yang mempengaruhi pekerjaan dan kesejahteraan umum pekerja. Penelitian ini menggunakan rancangan cross-sectional analitik dengan sampel penelitian adalah semua responden dengan keluhan nyeri punggung bawah memenuhi kriteria inklusi. Sampel dipilih dengan teknik purposive sampling dengan jumlah minimal adalah 76 sampel.

Tujuan: Tujuan penelitian ini adalah untuk mengetahui hubungan lama duduk terhadap nyeri punggung bawah miogenik dan faktorfaktor yang berhubungan pada pengerajin kain tenun di Desa Sidemen sehingga hasil penelitian dapat digunakan sebagai studi konfirmatif.

Metode: Hasil penelitian menunjukkan jumlah sampel terbanyak berdasarkan kelompok jenis kelamin perempuan $85,5 \%$ (65 orang), usia 25-50 tahun 75,0\% (57 orang), masa kerja > 10 tahun 90,8\% (69 orang), IMT yang tidak beresiko $(\leq 29,9)$ sebesar $63,2 \%$ (48 orang), untuk kebiasaan olahraga 1 kali dalam seminggu 94,7\% (72 orang), berdasarkan Pain Disability Index (PDI) terganggu dengan skor PDI 035 sebesar $96,1 \%$ (73 orang), berdasarkan lama duduk $>4$ jam sebesar $81,6 \%$ (62 orang), dan untuk keluhan nyeri punggung bawah tidak NPB sebesar 64,5\% (49 orang).

Simpulan: Hasil uji Exact Fisher memperoleh p 0,011 yang menandakan bahwa Ho ditolak yang artinya terdapat hubungan antara lama duduk terhadap nyeri punggung bawah miogenik pada pengerajin kain tenun di Desa Sidemen. PR (prevalensi rasio) didapatkan 5,871 yang artinya pengerajin kain tenun yang duduk $>4$ jam 5,871 kali lebih berisiko untuk mengalami nyeri punggung bawah dibandingkan yang duduk $<4$ jam.
Program Studi Pendidikan Dokter,

Fakultas Kedokteran Universitas

Udayana

dyahyusaa@gmail.com

Diterima: 08-04-2018

Disetujui: 16-06-2018

Diterbitkan: 01-08-2020
Kata Kunci: Nyeri Punggung Bawah (NPB), lama duduk, pengerajin kain tenun.

Cite Pasal Ini: Dhammayanthi, I.A.D.Y., Purnawati, S., Muliarta, M. 2020. Hubungan lama duduk terhadap nyeri punggung bawah miogenik dan faktor-faktor yang berhubungan pada pengerajin kain tenun di Desa Sidemen, Kecamatan Sidemen, Kabupaten Karangasem tahun 2017. Intisari Sains Medis 11(2): 878-883. D0l: 10.15562/ism.v11i2.226 


\section{PENDAHULUAN}

Kecamatan Sidemen, Kabupaten Karangasem destinasi wisata kerajinan tenun dengan kata lain sebagai pusat kerajinan kain tenun di Bali. Sebagian besar penduduk di Sidemen berprofesi sebagai pengrajin kain tenun. Hasil produksinya telah memasuki pasar lokal, nasional dan internasional. Sikap duduk pengrajin tenun sikap duduk yang statis yaitu sikap duduk di lantai menghadap ke arah alat tenun dan punggung dalam posisi sedikit membungkuk. Sikap duduk ini dilakukan rerata 8-9 jam/hari dan beberapa kali berdiri untuk mengambil sesuatu yang dibutuhkan termasuk waktu istirahat makan atau minum. Beban kerja statis ini menyebabkan kelelahan otot rangka disamping otot-otot beban kerja ini akan lebih parah lagi apabila lingkungan dan sikap kerja yang tidak ergonomis. Kondisi kerja yang tidak ergonomis merupakan suatu aspek dalam tuntutan tugas. Risiko - risiko yang yang dapat mempengaruhi kehidupan para pekerja adalah kemungkinan terjadinya penyakit akibat pekerjaan, penyakit yang berhubungan dengan pekerjaan dan kecelakaan kerja yang dapat mengakibatkan kecacatan ataupun kematian.

Ergonomi merupakan bidang ilmu yang mempelajari tentang hubungan antara manusia dengan kondisi kerjanya, yaitu keseluruhan alat perkakas dan bahan yang dihadapi, organisasi atau metode kerjanya dan sekitar lingkungan kerjanya. ${ }^{6}$ Selain itu menurut (Boschman, Molen, Sluiter, and Frings-dresen, 2012) ergonomi merupakan ilmu yang mempelajari kharakteristik dan kemampuan manusia yang mempengaruhi desain pekerjaan dan sistem kerja. ${ }^{2}$

Penyakit atau keluhan akibat kerja merupakan suatu kondisi yang diderita pekerja dalam hubungan dengan pekerjaannya, baik faktor risiko karena kondisi tempat kerja, peralatan kerja, material yang dipakai, proses produksi, cara kerja, limbah perusahaan dan hasil produksi. ${ }^{13}$ Salah satu penyakit yang diakibatkan oleh pekerjaan yang menjadi masalah kesehatan yang sering terjadi dan mempengaruhi hampir seluruh populasi adalah LBP (Low Back Pain) atau sering disebut dengan NPB (Nyeri Punggung Bawah). Nyeri punggung bawah merupakan suatu sindrom nyeri yang terjadi pada regio punggung bagian bawah yang diakibat oleh berbagai sebab. Kondisi ini paling banyak ditemukan di tempat kerja, terutama pada mereka yang beraktivitas dengan posisi tubuh yang salah. ${ }^{8}$

Nyeri punggung bawah bukan merupakan suatu penyakit ataupun diagnosis untuk suatu penyakit namun merupakan istilah untuk nyeri yang dirasakan di area anatomi yang terkena dengan berbagai variasi lama terjadinya nyeri. Nyeri punggung bawah merupakan penyebab utama gangguan kondisi tubuh yang mempengaruhi pekerjaan dan kesejahteraan umum. Keluhan NPB dapat terjadi pada semua orang, baik jenis kelamin, usia, ras, status pendidikan dan profesi. ${ }^{11}$

Klasifikasi NPB dapat dibagi menjadi 2 kelompok, yaitu kronik dan akut. Nyeri punggung bawah akut akan terjadi dalam kurang dari 12 minggu. Sedangkan nyeri punggung bawah kronik terjadi dalam waktu lebih dari 3 bulan. Nyeri punggung bawah berhubungan dengan stress atau strain otototot punggung, tendon dan ligamen yang biasanya ada bila melakukan aktivitas sehari-hari secara berlebihan, seperti duduk atau berdiri terlalu lama. Kebanyakan nyeri punggung bawah tidak mengakibatkan kecacatan tapi menyebabkan gangguan aktivitas kerja. ${ }^{12}$

Sekitar $80 \%$ dari populasi pernah mengalami nyeri punggung bawah paling tidak sekali dalam hidupnya. Hasil Studi Departemen Kesehatan RI meperoeh $40,5 \%$ dari pekerja memiliki keluhan gangguan kondisi kesehatan yang berhubungan dengan pekerjaannya yaitu gangguan otot rangka sebanyak 16\%. Hasil laporan pelaksanaan kesehatan kerja di 26 Provinsi di Indonesia tahun 2013, jumlah kasus penyakit umum pada pekerja ada sekitar 2.998.766 kasus, dan jumlah kasus penyakit yang berkaitan dengan pekerjaan berjumlah 428.844 kasus. Sehingga berdasarkan data tersebut perlu dilakukan pendekatan mengenai upaya upaya untuk mengantisipasi risiko - risiko tersebut melalui cara penyesuaian antar pekerja, proses kerja dan lingkungan kerja yang disebut dengan pendekatan ergonomi. ${ }^{12}$

Low Back Pain (LBP) merupakan salah satu dari 15 kondisi medis paling mahal di AS, dan prevalensi LBP terus meningkat, dengan $28 \%$ dari orang dewasa sekarang melaporkan LBP selama 3 bulan terakhir. Kebanyakan orang sembuh dari episode akut LBP dan dapat kembali bekerja dalam beberapa hari atau minggu, tapi untuk beberapa kasus, rasa sakit berkembang menjadi kronis dan dapat melumpuhkan dengan kondisi implikasi seumur hidup. Studi prognostik pasien dengan LBP akut telah menunjukkan bahwa hampir $40 \%$ berada pada risiko tinggi (10-15\% dan berisiko tinggi) dari mengembangkan cacat kronis berdasarkan jumlah faktor resiko ini. ${ }^{3}$ Beban sikap tubuh statis yang lama menjadi faktor yang utama dalam kehidupan modern, yang menjadi penyebab nyeri otot rangka akibat kerja. ${ }^{5}$ Di Amerika Serikat keluhan nyeri otot-otot rangka merupakan salah satu penyakit akibat kerja sehingga menyebabkan menyebabkan hampir sebagian besar tenaga kerja 
menderita "Musculosketal Disorder" dan "Low Back Pain". ${ }^{14}$

Insiden NPB di populasi ditemukan sebanyak 15-20\%. Dan 98\% di antaranya disebabkan oleh faktor mekanik karena ketegangan otot dan ligamentum tulang belakang. ${ }^{15}$ Salah satu faktor karena gangguan mekanikal tersebut adalah duduk lama. Pada penelitian memperoleh sekitar 39,7 - 60\% orang mengalami NPB akibat duduk lama. ${ }^{16}$

Mengingat tingginya akan kejadian dan faktor resiko yang dapat menyebabkan terjadinya NPB, maka peneliti tertarik untuk melakukan penelitian untuk mengetahui apakah ada hubungan lama duduk terhadap terjadinya nyeri punggung bawah.

\section{METODE}

Penelitian ini merupakan penelitian analitik cross-sectional. Penelitian dilaksanakan pada bulan Maret - April 2017 bertempat di wilayah Desa Sidemen, Kecamatan Sidemen, Kabupaten Karangasem. Kriteria sampel penelitian ini adalah semua pengerajin kain tenun di lingkungan Desa Sidemen, Kecamatan Sidemen, Kabupaten Karangasem Tahun 2017. Sampel yang dipilih dari populasi memenuhi kriteria inluksi yaitu bersedia menjadi subjek penelitian dan berusia 25-65 tahun. Serta tidak memenuhi kriteria eklusi yaitu sampel memiliki riwayat trauma signifikan, nyeri yang terdapat pada bagian atas tulang belakang, memiliki penyakit kongenital seperti kifosis berat, lordosis berat atau scoliosis berat.

Teknik penentuan sampel yang digunakan pada penelitian ini yaitu purposive sampling. Besar sampel dalam penelitian ini dihitung menggunakan rumus data nominal (sampel tunggal untuk perkiraan rerata):

$\mathrm{n}=\left[\frac{\mathrm{Za}^{2} \mathrm{PQ}}{\mathrm{d}^{2}}\right]$

$\mathrm{n}=$ besar sampel

$\mathrm{Za}=$ tingkat kemaknaan (1,96 pada Confidence Interval 95\%)

$\mathrm{P}=27 \%$ (Estimasi proporsi NPB berdasarkan penelitian oleh Wulandari, I. D., 2010)

$\mathrm{q}=(1-\mathrm{P})$

$\mathrm{d}=$ tingkat ketepatan absolut yang diinginkan (ditetapkan)

Maka:

$$
\begin{aligned}
\mathrm{n}= & {\left[\frac{1,96^{2} \times 0,1971}{0,1^{2}}\right] } \\
\mathrm{n}= & 75,7 \text { sampel, dibulatkan menjadi } \\
& 76 \text { sampel. }
\end{aligned}
$$

Adapun variabel-variabel yang diteliti pada penelitian ini adalah lama duduk, usia, masa kerja, jenis kelamin, IMT (index massa tubuh) dan kebiasaan olahraga. Variabel independen dalam penelitian ini adalah lama duduk serta faktor internalnya yaitu usia, masa kerja, jenis kelamin, IMT (index massa tubuh) dan kebiasaan olahraga. Variabel dependen dalam penelitian ini adalah keluhan nyeri punggung bawah miogenik.

Analisis univariat digunakan untuk mengetahui gambaran atau deskripsi dari variabel penelitian dengan hasil berupa distribusi dan presentase variabel. Variabel penelitian ini terdiri dari variabel independen yaitu distribusi spesifik lama duduk, usia, masa kerja, jenis kelamin, kebiasaan merokok, IMT (index massa tubuh) dan kebiasaan olahraga. Analisis bivariat adalah analisis yang dilakukan pada dua variabel yang diduga berhubungan. Analisis bivariat yang digunakan merupakan Chi-square untuk menentukan adanya hubungan antara lama duduk terhadap keluhan nyeri punggung bawah serta hubungan antara masing-masing faktor risiko (usia, masa kerja, jenis kelamin, IMT dan kebiasaan olahraga) terhadap keluhan nyeri punggung bawah. Analisis regresi logistik ganda merupakan analisis yang dilakukan untuk meneliti dua atau lebih variabel independen terhadap satu variabel dependen. Variabel independennya adalah variabel independen yang bermakna pada uji Chisquare. Variabel dependennya adalah nyeri punggung bawah.

\section{HASIL PENELITIAN}

Penelitian ini dilaksanakan pada bulan Mei 2017 bertempat di wilayah Desa Sidemen, Kecamatan Sidemen, Kabupaten Karangasem. Jumlah responden penelitian ini terdiri dari 76 pengrajin kain tenun yang telah memenuhi kriteria inklusi. Karakteristik responden penelitian berdasarkan jenis kelamin, usia, masa kerja, IMT (index massa tubuh), kebiasaan olahraga, PDI (Pain disability index), lama duduk, dan keluhan nyeri punggung bawah dapat dilihat pada Tabel 1 dan Tabel 2 berikut.

Berdasarkan Tabel 1 dan Tabel 2, menunjukkan lebih banyak pengrajin kain tenun yang berjenis kelamin perempuan dari pada laki-laki. Untuk distribusi usia menunjukkan bahwa pengrajin kain tenun lebih banyak direntang usia 25-50 tahun. Berdasarkan masa kerja tampak dominan $>10$ tahun sebesar 90,8\% (69 orang). Berdasarkan index massa tubuh menunjukkan pengrajin kain tenun lebih banyak yang memiliki IMT $\leq 22,9$ atau tidak beresiko.

Untuk kebiasaan olahraga dalam seminggu. menunjukkan pengrajin kain tenun di Desa 
Tabel 1 Karakteristik Pengerajin Kain Tenun Desa Sidemen berdasarkan Jenis Kelamin, Usia, Masa Kerja, IMT, dan Kebiasaan Berolahraga

\begin{tabular}{lcc}
\hline Variabel & Frekuensi & Persentase \\
\hline Jenis Kelamin & 11 & 14,5 \\
$\quad$ Laki-laki & 65 & 85,5 \\
$\quad$ Perempuan & & \\
Usia & 57 & 75,0 \\
$\quad 25-50$ tahun & 19 & 25,0 \\
$>50$ tahun & & \\
Masa Kerja & 7 & 9,2 \\
$\quad<10$ tahun & 69 & 90,8 \\
$\quad>10$ tahun & & 36,8 \\
IMT & 28 & 63,2 \\
Beresiko & 48 & 94,7 \\
Tidak Beresiko & & 5,3 \\
Kebiasaan Olahraga & 72 & \\
1 Kali per minggu & 4 & \\
$>1$ kali per minggu & & \\
\hline
\end{tabular}

Tabel 2 Karakteristik pengerajin kain tenun Desa Sidemen berdasarkan Pain Disability Index (PDI), lama duduk, dan keluhan NPB

\begin{tabular}{lcc}
\hline Variabel & Frekuensi & Persentase (\%) \\
\hline PDI & 73 & \\
$\quad$ Sedikit Terganggu & 3 & 36,1 \\
$\quad$ Sangat Terganggu & & \\
Lama Duduk & 14 & 18,4 \\
$\quad<4$ jam & 62 & 81,6 \\
$>4$ jam & & \\
Keluhan NPB & 27 & 35,5 \\
NPB & 49 & 64,5 \\
Tidak NPB & &
\end{tabular}

Tabel 3 Hasil Analisis Statistik Hubungan antara Faktor Risiko Terhadap Keluhan Nyeri Punggung Bawah menggunakan Uji Exact Fisher

\begin{tabular}{|c|c|c|c|c|c|c|c|}
\hline \multirow[b]{3}{*}{ Lama Duduk } & \multicolumn{4}{|c|}{$\begin{array}{c}\text { Keluhan Nyeri Punggung } \\
\text { Bawah }\end{array}$} & \multirow[b]{3}{*}{$\mathbf{p}$} & \multirow[b]{3}{*}{$95 \% \mathrm{Cl}$} & \multirow[b]{3}{*}{ PR } \\
\hline & \multicolumn{2}{|c|}{ Ada } & \multicolumn{2}{|c|}{ Tidak } & & & \\
\hline & $\mathbf{N}$ & $\%$ & $\mathbf{N}$ & $\%$ & & & \\
\hline$>4$ jam & 26 & 34,2 & 36 & 47,3 & \multirow{2}{*}{0.011} & \multirow{2}{*}{$0,87-39,70$} & \multirow{2}{*}{5,871} \\
\hline$<4$ jam & 1 & 1,3 & 13 & 17,2 & & & \\
\hline
\end{tabular}

Sidemen lebih banyak yang melakukan olahraga 1 kali dalam seminggu. Berdasarkan Pain Disability Index (PDI) pengrajin kain tenun di
Desa Sidemen sebagian besar mengalami tingkat nyeri yang tidak terlalu menggangu pada tujuh area aktivitas kehidupanya (keluarga/tanggung jawab rumah, rekreasi, aktivitas sosial, pekerjaan, perilaku seksual, self-care dan pendukung aktivitas kehidupan). Berdasarkan lama pengrajin kain tenun lebih banyak yang duduk $>4$ jam dari pada yang duduk $<4$ jam. Untuk keluhan nyeri punggung bawah menunjukkan bahwa pengrajin kain tenun lebih banyak yang tidak mengeluhkan nyeri punggung bawah daripada mengeluhkan nyeri pada punggung bawahnya.

\section{Hubungan Antara Lama Duduk Terhadap Keluhan Nyeri Punggung Bawah}

Dari hasil Tabel 3 menunjukan bahwa berdasarkan lama duduk responden menunjukan bahwa dari 14 responden yang lama duduk $<4$ jam dalam sehari, terdapat 1 responden $(1,3 \%)$ mengalami keluhan nyeri punggung bawah dan 13 responden $(17,2 \%)$ tidak mengalami keluhan nyeri punggung bawah. Sedangkan dari 62 responden yang lama duduk $>4$ jam dalam sehari, terdapat 26 responden $(34,2 \%)$ mengalami keluhan nyeri punggung bawah dan 36 responden $(47,3 \%)$ tidak mengalami keluhan nyeri punggung bawah. Dari Uji Exact Fisher yang dilakukan terhadap lama duduk dengan keluhan nyeri punggung bawah didapatkan $p$ value $=$ 0,011 yang berarti $p$ value kurang dari 0,05 ( $\mathrm{p}<$ 0,05 ), sehingga Ho ditolak dan Ha diterima yaitu ada hubungan antara lama duduk dengan keluhan nyeri punggung bawah pada pengrajin kain tenun di Desa Sidemen. PR (prevalensi rasio) didapatkan 5,871 yang artinya pengerajin kain tenun yang duduk $>4$ jam 5,871 kali lebih berisiko untuk mengalami nyeri punggung bawah dibandingkan yang duduk $<4$ jam.

\section{DISKUSI}

Lama duduk mempunyai hubungan dengan nyeri punggung bawah miogenik. Hal ini semakna dengan kajian pustaka yang menyatakan dalam penelitian yang dilakukan oleh Samara dkk yang melakukan studi case control dan menemukan bahwa duduk selama 1,5 sampai 5 jam memiliki risiko 2,35 kali lebih besar untuk terjadi nyeri punggung bawah miogenik. Seseorang yang bekerja dengan posisi duduk selama setengah hari atau lebih mempunyai risiko relatif 1,6 kali untuk terjadi nyeri punggung bawah miogenik. ${ }^{18}$ Penelitian serupa juga dilakukan oleh Sari dkk menyatakan bahwa ada hubungan lama duduk dan keluhan NPB. ${ }^{19}$ Pada penelitian yang dilakukan Sumekar dan Natalia menemukan bahwa lama 
duduk $>4$ jam menyebabkan terjadinya NPB pada hampir semua sampel penelitian. ${ }^{20}$ Kondisi lama duduk $>4$ jam menyebabkan lebih sering terjadi gangguan sehingga terjadi kelelahan dan iskemia jaringan di sekitar region tersebut. Regio nyeri yang luas dirasakan di sekitar vertebra lumbalis sehingga mempunyai risiko lebih besar untuk menjadi nyeri yang disebabkan oleh kondisi hiperalgesia. Sehingga disela-sela waktu bekerja harus istirahat selama $15-30 \%$ dari lamanya waktu saat bekerja. Jika jam kerja melampaui dari yang seharusnya akan kondisi penurunan efektivitas kerja, gangguan kesehatan, angka absensi karena sakit meningkat, yang dapat mengakibatkan rendahnya tingkat produktivitas kerja. ${ }^{21}$

\section{SIMPULAN}

Derajat keluhan nyeri punggung bawah pada pengrajin kain tenun di Desa Sidemen sebagian besar $(96,1 \%)$ mengalami tingkat nyeri yang tidak terlalu menggangu. PR (prevalensi rasio) didapatkan 5,871 yang artinya pengerajin kain tenun yang duduk $>4$ jam 5,871 kali lebih berisiko untuk mengalami nyeri punggung bawah miogenik dibandingkan yang duduk $<4$ jam. Terdapat hubungan yang signifikan antara lama duduk dengan keluhan nyeri punggung bawah niogenik pada pengrajin kain tenun di Desa Sidemen $(\mathrm{p}<0.05)$.

\section{SARAN}

Pengrajin yang mengalami keluhan nyeri pada punggung bawah yang disebabkan oleh lama duduk, hal ini dapat dicegah dengan penambahan bantal di tempat duduk maupun disandaran tenun ataupun dapat diberi gulungan handuk kecil untuk mempertahankan kurva tulang belakang. Selingi dengan meregangkan otot-otot dengan berdiri sejenak di sela-sela pekerjaan. Istirahat selama 15 menit setelah bekerja selama 2 jam atau seteah melakukan pekerjaan yang berat. Selama duduk istirahatkan siku dan lengan pada samping alat tenun, jaga bahu agar tetap rileks. Bagi tenaga kerja yang berusia $\geq 35$ tahun sebaiknya mengkonsumsi makanan atau minuman yang mengandung kalsium tinggi dan memperhatikan kondisi fisik tubuhnya pemeriksaan kesehatan secara berkala terutama tentang keluhan nyeri punggung bawah. Bagi peneliti yang akan melaksanakan penelitian yang sejenis diharapkan dapat meneliti mengenai faktor yang belum diteliti, serta diharapkan dapat mengobservasi PDI secara objektif dan mengembangkan penelitian dengan desain lain selain cross sectional.

\section{DAFTAR PUSTAKA}

1. Boot, R. L. 2013. Cumulative Low Back Load at Work as a Risk Factor of Low Back Pain : A Prospective Cohort Study, 11-18. Available from: http://doi.org/10.1007/ s10926-012-9375-z Cited: 23 Juni 2015.

2. Boschman, J. S., Molen, H. F. Van Der, Sluiter, J. K., and Frings-dresen, M. H. W. 2012. Musculoskeletal disorders among construction workers : a one-year follow-up study Musculoskeletal disorders among construction workers : a one-year follow-up study. BMC Musculoskeletal Disorders, 13(1), 1. Available From: http://doi.org/10.1186/14712474-13-196 Cited: 23 Juni 2015.

3. Endresen, S., William, R., Steenstra, I. A., Jane, M., Pransky, G., and Linton, S. J. 2012. Distressed, Immobilized, or Lacking Employer Support? A Sub-classification of Acute Work-Related Low Back Pain; 541-552. Available from: http://doi.org/10.1007/s10926-012-9370-4 Cited: 23 Juni 2015

4. George, E., \& Thomas, J. 2002. A new direction in low-back pain research. Cited: 2 Juli 2015

5. Gupta, N., Christiansen, C. S., Hallman, D. M., and Korsh, M. 2015. Associated with Low Back Pain A Cross- Sectional Investigation in the NOMAD study, 1-19. Available from: http://doi.org/10.1371/journal.pone.0121159 Cited: 23 Juni 2015.

6. Kaminskas, K. A., and Antanaitis, J. 2005. A CROSSSECTIONAL SURVEY OF CONSTRUCTION WORKERS : AN ERGONOMIC APPROACH, (David). Cited: 23 Juni 2015.

7. Macgregor, L. A. J., Dougherty, A. L., Mayo, J. A., Rauh, M. J., and Galarneau, M. R. 2012. Occupational Correlates of Low Back Pain Among U. S. Marines Following Combat Deployment, 177 (November 2008), 845-850. Cited: 23 Juni 2015

8. Nursing, P., and Source, A. H. 2001. Interrelations of risk factors and low back pain in scaffolders. Cited: 2 Juli 2015.

9. Rene, C. E. D., and Fre, P. 2013. Obstacles to and Facilitators of Return to Work After Work-Disabling Back Pain : The Workers 'Perspective, 280-289. Available from: http://doi. org/10.1007/s10926-012-9399-4 Cited: 23 Juni 2015.

10. Stewart, A. M., Polak, E., Young, R., \& Schultz, I. Z. 2012. Injured Workers ' Construction of Expectations of Return to Work with Sub-Acute Back Pain : The Role of Perceived Uncertainty, 1-14. Available from: http://doi.org/10.1007/ s10926-011-9312-6 Cited: 23 Juni 2015.

11. World Health Organization, 2013. Low Back Pain. Ehrlich, George E. Philadelphia. Bulletin of the World Health Organization.

12. Wulandari, I. D., 2010. Hubungan Lama dan Sikap Duduk Perkuliahan terhadap Keluhan Nyeri Punggung Bawah Miogenik pada Mahasiswa di Universitas Muhammadiyah Surakarta. Jawa Tengah. Universitas Muhammadiyah.

13. Pirade A, Angliadi E, Sengkey L. S., 2013. Hubungan Posisi dan Lama Duduk dengan Nyeri Punggung Bawah (NBP) Mekanik Kronik pada Kariawan Bank. Manado. Universitas Sam Ratulangi.

14. Mayasari P, Kustono D, Devi M. 2016. Faktor-faktor Ergonomi yang Berhubungan dengan Produktivitas Kerja di Sentra Industri. Malang. Universitas Negeri Malang.

15. Nurrahman, M. 2016. Hubungan Masa Kerja dan Sikap Kerja terhadap Kejadian LBP pada Penenun di Kampoeng BNI Kabupaten Wajo. Makasar. Universitas Hasanuddin.

16. Santosa A, Widyadharma P, Purwata T E. 2016. Korelasi Lama Duduk dengan Nyeri Punggung Bawah pada Pekerja Hotel The Grand Santhi Denpasar. Bali. Universitas Udayana. 
17. Guyton, A.C, Hall, J,E 2014. Buku Ajar Fisiologi Kedokteran. Edisi 12. Jakarta EGC.

18. Samara, D. 2004.Lama dan Sikap Duduk sebagai Faktor Risiko Terjadinya Nyeri Punggung Bawah.Fakultas Kedokteran Universitas Trisakti.

19. Sari, N.P., Mogi, T.I., Anggliadi, E.2015. Hubungan Lama Duduk dengan Kejadian Low Back Pain Pada Operator Komputer Perusahaan Travel di Manado.Manado. Universitas Sam Ratulangi.

20. Sumekar, D.W., Natalia, D. 2010. Nyeri Punggung pada Operator Komputer Akibat Posisi dan Lama Duduk. Lampung. Universitas Lampung.
21. Yusuf, H., Dewi, D.R.L., Fitrianingrum, I. 2014. Hubungan antara Lama Duduk dan Sikap Duduk terhadap Kejadian Nyeri Punggung Bawah di Poliklinik Saraf RSUD Dokter Soedarso Pontianak.Kalimantan.

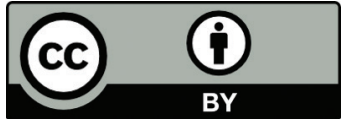

This work is licensed under a Creative Commons Attribution 